\title{
HEMICELLULASES PRODUCTION BY AEROBIC FUNGI USING BANANA PLANT RESIDUE AS SUBSTRATE
}

\author{
Ranjeet Singh \& S.K. Mandal*
}

\section{Summary}

Trichderma harzimum strains MTCC 792, T. longibractium MTCC 936, Acrophilaphora nainiana MTCC 885 and Humicola grisea NCIM 352 var. thermoidea were screened for their ability to produce carbohydrate degrading enzyme activities in a medium containing banana plant residue as the carbon source. The best balance of enzyme activities was obtained from cultures of $\mathrm{H}$. grisea NCIM 352 var. thermoidea. Xylanase activity from crude extracts of $A$. nainina MTCC 885 had a maximum activity at $\mathrm{pH} 5 \cdot 5-7.0$ and temperature range of $50^{\circ}-55^{\circ} \mathrm{C}$ and fungi were also able to produce xylanase and pectinase activities when grown on extractives as substrate at $\mathrm{pH} 7.0$ for $24 \mathrm{hrs}$.

\section{Introduction}

Agricultural and forestry biomasses contain lignocellulosic material available for exploitation as source of chemical feedstocks, fuels and feeds (Archana, 1997). In recent years, the use of such materials has also become an alternative approach for the production of cellulose pulp. The banana plant (Musa paradisiciaca) produces

* Department of Biochemical Engg. and Food Technology, Harcourt Butler Technological Institute, Kanpur-208002, India. 
a residual component named fruit stalk. Hemicellulose and lignin accounts for as much as $33 \%$ and $8.67 \%$ of the dry weight of this component, respectively. Moreover, this residual component produces a high level of extractives containing polyphenols, pectin and hemicelluloses. These extractives are reported to effect the manufacture of pulp and paper, reducing lignin solubility and the yield of Kraft pulp and increasing chemical consumption equipment corrosion (Gardner et al., 1962). Therefore, the use of fruit stalk as an alternative source of cellulose for the pulp and paper industry requires the removal of extractives before the pulping process. For bioconversion of these materials it is desirable to have a microorganism capable of producing a variety of enzymes that interact synergistically (Kyu et al., 1994). This present reports discusses the enzymatic hydrolysis of a residual component from the banana (fruit stalk) and its extractives by Trichoderma harzimum strains MTCC 792, T. longibractium MTCC 936, Acrophialophora naininana MTCC 885, and Humicola grisea NCIM 352 var. thermoidea.

\section{Materials and Methods}

\section{Fungal Strain}

Trichoderma harzimum MTCC 792, T. longibractium MTCC 792, Acrophilophora naininiana MTCC 885, Humicola grisea NCIM 352 procured from Chandigarh and Pune.

\section{Chemicals}

In this study sodium nitrate, dipotassium hydrogen phosphate, magnesium sulphate, potassium chloride, sodium hydroxide, manganese sulphate, ferrous sulphate, cobalts chloride, zinc sulphate, ammonium molybdate, hydrochloric acid, diammonium sulphate, copper sulphate, disodium carbonate, cuprous oxide, phenolphthalein, phenol, ammonium oxalate, ammonium solution, petroleum ether and reactified spirit agar agar of bacteriological, dextrose. These were procured from S.D. fine, SRL, CDH and Ranbaxy and all enzyme assay substrates were purchased from FLUKA chemical co. (Belzium), fruit stalk as from a local source. The extraction of fruit stalk extractives was carried out by refluxing the preparation for $16 \mathrm{~h}$ in ethanol. Tolvene-ethanol $(2: 1)$, and distilled water, respectively. The resulting material was evaporated to dryness af $105 \pm 2{ }^{\circ} \mathrm{C}$.

\section{Enzyme Production}

Flasks containing $1.0 \%(\mathrm{w} / \mathrm{v})$ banana fruit stalk or spelt xylan in $100 \mathrm{ml}$ of supplemented medium $10.7 \% \mathrm{KH}_{2} \mathrm{PO}_{4}, 0.2 \% \mathrm{~K}_{2} \mathrm{HPO}_{4}, 0.05 \% \mathrm{MgSO}_{4}, 7 \mathrm{H}_{2} \mathrm{O}$, 
$0.1 \%\left(\mathrm{NH}_{4}\right)_{2} \mathrm{SO}_{4}$, and $0.06 \%$ yeast extract) were inoculated with $1 \times 10^{6} / \mathrm{ml}$ of spore suspensions from routine subcultures and incubated at $28^{\circ} \mathrm{C}$ (T. horzimum strains MTCC 792, T. longibractium MTCC 936) and $40^{\circ} \mathrm{C}$ (H. grisea NCIM 352 var. thermoidea and $A$. nainiana MTCC 885) at ph 7.0 for 7 days with shaking at $100 \mathrm{rm}$. The content of each flask was filtered through filter paper. The supernatants obtained from the filtration procedure were stored at $40^{\circ} \mathrm{C}$ for subsequent use as enzyme assay solutions. The growth on extractive material as substrate was performed as described above in the absence of supplemented medium. Cultures of the above fungi were inoculated with spore suspensions and $50 \mathrm{ml}$ of medium and grown for 8 days, after which samples were taken for determination of mycelial dry weight, reducing sugar, protein content, and xylanase and pectinase activities. The mycelia were washed with distilled water and dried at $95^{\circ} \mathrm{C}$ to constant weight. A. nainiana MTCC 885 was also grown for 15 days in $200 \mathrm{ml}$ of culture medium containing fruit stalk in a concentration range of $0.5-1.5 \%$ at the same conditions as described before. Each experiment above repeated at least three times. The standard deviation was less than $\pm 20 \%$ of the mean.

\section{Assays of all Enzymes}

The $\beta$-xylosidase activity was estimated using $\mathrm{pNPX}$ as substrate, $0.1 \mathrm{ml}$ of suitably diluted enzyme was mixed with $0.9 \mathrm{ml}$ of substrate $11 \mathrm{mg} / \mathrm{ml}$ in $0.05 \mathrm{M}$ citrate buffer, $\mathrm{pH} 4.5$ ) and the mixture incubated at $65^{\circ} \mathrm{C}$ for $30 \mathrm{~min}$. the reaction was stopped by adding $2 \mathrm{ml}$ of sodium carbonate (2\%) and the amount of $\mathrm{p}$-nitrophenol produced was measured at $410 \mathrm{~nm}$. A unit of activity is expressed as the amount of xylose or p-nitrophenol produced per min per millilitre of the culture filtrate.

Xylanase activity was estimated by determining the release of reducing sugars from xylan. The reaction mixture contained $1 \mathrm{ml}$ enzyme preparation appropriately diluted in $0.1 \mathrm{M}$ pottasium phosphate buffer $\mathrm{pH} 7.0$ plus $1 \mathrm{ml}$ substrate suspension $\left(10 \mathrm{mg} \mathrm{m}^{-1}\right.$ xylan in phosphate buffer). Controls, in which enzyme preparation or substrate had been omitted, were routinely included. Assay mixture were incubated for $15 \mathrm{~min}$ with shaking at $55^{\circ} \mathrm{C}$. reducing sugar method was determined by the dinitrosalicylic acid (DNS) method and enzyme activity expressed as $\mu$ moles D. xylose equivalents released $\mathrm{min}^{-1}$ (IU). Cellulose assays were identical to xylanase assays. Except that cellulose was used as the substrate and activity was expressed as micromoles of reducing sugar (as glucose) liberated per minute per millilitre of undiluted enzyme.

The arabinofuranosidase activity was measured by mixing a volume of an appropriate dilution of the enzyme $\left(90 \mathrm{mg} \mathrm{m}^{-1}\right.$ final concentration) with a solution of $p$-nitrophenyl or methyl umbellifery derivative $\left(0.8 \mathrm{mg} \mathrm{m}^{-1}\right.$ final concentration) $20 \mathrm{mMMES}$ buffer ( $\mathrm{pH}$ 6.5). The mixture was incubated for $8 \mathrm{~min}$ at $50^{\circ} \mathrm{C}$, one volume of $1 \mathrm{M}$ 
$\mathrm{NaCO}_{3}$ was added to the sample. The release of $p$-nitrophenol was measured at $420 \mathrm{~nm}$ and the release of methylumbelliferone was measured at $365 \mathrm{~nm}$. Blanks was prepared by incubating enzyme and substrate solution separately. One unit of activity was defined as the amount of enzyme releasing $l \mu \mathrm{mol}$ of $\mathrm{p}$-nitrophenol or methyl umbelliferone $\mathrm{min}^{-1}$.

The hydrolysis of polysaccharides (pectin and mannas, $1.0 \%, w / v$ ) p-nitrophenyl$\beta$-D-mannopyranoside was determined at $50^{\circ} \mathrm{C}$ in $50 \mathrm{mM}$ sodium acetate buffer, pH 5.0 as described elsewhere (Ximenes et al., 1999). Enzyme activities were expressed as $\mu \mathrm{mol}$ product formed $\mathrm{min}^{-1} \mathrm{ml}^{-1}$ of enzyme solution, i.e., as $\mathrm{UU} \mathrm{mL}^{-1}$. Protein concentration was measured by the method of Bradford (Bradford, 1999), using bovine serum albumin as the standard.

\section{Results and Discussion}

Table 1. Some properties of crude extracts from T. harzimum strains MTCC 792, T. longibractium MTCC 936 A. nainiana MTCC 885, and H. grisea NCIM 352 var, thermoidea when grown in different substrates.

\begin{tabular}{|l|l|l|l|l|l|l|}
\hline Fungus & Substrate & $\begin{array}{c}\text { Dry } \\
\text { weight } \\
(\mathrm{mg} / \mathrm{ml})\end{array}$ & $\begin{array}{c}\text { Xylanase } \\
\text { activity } \\
(\mathrm{UU} / \mathrm{ml})\end{array}$ & $\begin{array}{c}\text { Pectinase } \\
\text { activity } \\
(\mathrm{IU} / \mathrm{mol})\end{array}$ & $\begin{array}{c}\text { Redusing } \\
\text { sugar } \\
(\mathrm{mg} / \mathrm{ml})\end{array}$ & $\begin{array}{c}\text { Protein } \\
\text { conc. }\end{array}$ \\
\hline T. longibractium & Xylan & 4.50 & 6.690 & 0.518 & 0.520 & 0.015 \\
MTCC 936 & Exit stalk & $\mathrm{nd}^{*}$ & 5.696 & 0.365 & 0.562 & 0.018 \\
\hline T. harzimum & Xylan & 4.520 & 3.773 & 0.601 & 0.433 & 0.011 \\
MTCC 792 & Fruit stalk & nd* & 2.333 & 0.624 & 0.445 & 0.013 \\
& extractives & 0.100 & 0.343 & 0.547 & 0.589 & 0.015 \\
\hline A. nainiana & Xylan & 3.978 & 4.960 & 0.470 & 0.278 & 0.009 \\
MTCC 885 & Fruit stalk & nd* & 2.800 & 0.900 & 0.335 & 0.014 \\
& Extractives & 0.220 & 0.585 & 0.504 & 0.705 & 0.016 \\
\hline H. grisea NCIM & Xylan & 3.880 & 5.420 & 0.584 & 0.535 & 0.008 \\
352 & Fruit stalk & nd* & 6.210 & 0.686 & 0.664 & 0.016 \\
& Extractives & 0.260 & 0.470 & 0.548 & 0.588 & 0.017 \\
\hline
\end{tabular}

(nd* not detected)

T. harzimum strains MTCC 792, T. longibractium MTCC 936, A. nainiana MTCC 885 , and H. grisea NCIM 352 var. thermoidea were able to grow on medium 
containing as substrate. The dry weight, reducing sugar, protein content, and xylanase and pectinase activities were compared with those in the medium containing oat spelt xylan or fruit stalks substrates (Table 1). In all cases, growth of the mycelium was less significant in extractives than in xylan. Unfortunately, it was not possible to determine the dry weight in media containing fruit stalk. Most of the substrates were found to be bound to the mycelium. Extractives did not induce xylanase to an appreciable extent. Low levels of xylanase activity were found in cultures containing pure extractives. A. nainiana MTCC 885 and H. Grisea NCIM 352 var.thermoidea being the best producers, a more pronounced inductive effect of extractives, on enzyme activity was obtained for pectinase. Higher amounts of pectinase activity were detected in cultures of $H$. grisea NCIM 352 var. thermoidea, A. nainiana MTCC 885, and T. harzimum strain MTCC 792. In comparison to the growth on xylan or fruit stalk as substrates, the amount of reducing sugar found with extractives medium was notably higher in A. nainiana MTCC 885 and T. harzimum strain MTCC 792. Low amounts of total protein were detected in ail cultures.

Table 2. Carbohydrate degrading enzyme production by liquid state cultures of H. grisea NCIM 352 var. thermoidea T. harzimum MTCC 792, T. longibractium MTCC 936, A. nainiana MTCC 885 grown on fruit stalk substrate.

\begin{tabular}{|l|l|l|l|l|l|}
\hline Fungus & $\begin{array}{l}\beta- \\
\text { mannanase }\end{array}$ & $\begin{array}{l}\beta- \\
\text { xylosidase } \\
(\mathrm{IU} / \mathrm{ml})\end{array}$ & $\begin{array}{l}\beta- \\
\text { xylosidase } \\
(\mathrm{IU} / \mathrm{ml})\end{array}$ & $\begin{array}{l}\alpha- \\
\text { arabinofura } \\
\text { nosidase }\end{array}$ & $\begin{array}{l}\text { Cellulose } \\
(\mathrm{IU} / \mathrm{ml})\end{array}$ \\
\hline $\begin{array}{l}\text { T. harzimum } \\
\text { MTCC 792 }\end{array}$ & 0.451 & 2.95 & 0.028 & 0.450 & 2.97 \\
\hline $\begin{array}{l}\text { T. longibractium } \\
\text { MTCC 936 }\end{array}$ & 0.461 & 4.25 & 0.075 & 0.462 & 4.23 \\
\hline $\begin{array}{l}\text { A. nainiana } \\
\text { MTCC 885 }\end{array}$ & 0.510 & 3.40 & 0.028 & 0.034 & 0.460 \\
\hline $\begin{array}{l}\text { H.grisea } \\
\text { NCIM 352 }\end{array}$ & 1.472 & 5.15 & 0.03 & 0.053 & 0.970 \\
\hline
\end{tabular}

The above fungi were examined for their ability to produce enzymes capable of breaking down fruit stalk (Table 2). The inductive effect of complex substrates xylandegrading enzymes ( $\beta$-xylanase, $\beta$-xylosidase and $\alpha$-arabinofuranosidase). $\beta$ mannanase and cellulase activities were inducible. The best balance of xylanase activity was found in crude extracts samples of $\mathrm{H}$. grisea NCIM 352 var. thermoidea and T. longibractium MTCC 936. With respect to mannanase, arabinofuranosidase and cellulase activities, the best yields were obtained with extracts of cultures of $H$. grisea NCIM 352 var. thermoidea and A. nainiana MTCC 885. $\beta$-Xylosidase 
was most active in the extract of a culture of T. longibractium MTCC 936 mannosidase activity was not detected in any of the crude extract samples.

The effect of fruit stalk concentration on the production of xylanase activity by $A$. nainiana MTCC 885 was examined by adding different concentration of substrate to the culture media. A residual xylanase activity appeared at $24 \mathrm{~h}$. In all cases, a relevant xylanase activity appeared at the 2 nd day, suggesting an inductive mechanism. The total protein content was also increased for the same period of incubation. Xylanase activity reached its maximum at the 2 nd day and $1.5 \%$ fruit stalk and declined. The growth at $0.5 \%$ and $1.0 \%$ fruit stalk behaved differently, xylanase activity increased throughout the 2 nd day of the experiments. The lowest level of enzyme activity was obtained at a fruit stalk concentration of $0.5 \%$. In comparison to the Xylanase activity from A. nainiana MTCC 885 when grown on fruit stalk as is also directly dependent on the substrate concentration present in the medium.

Xylanase activity from a crude extract of $A$. nainiana MTCC 885 grown on $1.0 \%$ fruit stalk showed a broad $\mathrm{pH}$ activity profile and was most active over a $\mathrm{pH}$ range of 5.5-7.0. The optimum temperature value was around $50^{\circ}-55^{\circ} \mathrm{C}$ at $\mathrm{pH} 5.0$. Xylanase retained $70 \%$ of its original activity for at least $2 \mathrm{~h}$ at $55^{\circ} \mathrm{C}$ and $\mathrm{pH} 7.0$. It dropped to almost $50 \%$ and $24 \%$ after 3 and 24 h of incubation respectively.

\section{Conclusion}

In conclusion, T. harzimum strains MTCC 792, T. longibractium MTCC 936, H. grisea NCIM 352 var. thermoidea and A. nainiana MTCC 885 produced different levels of carbohydrate - degrading enzyme system when grown in the presence of fruit stalk and extractives as substrates. These isolates, notably H. grisea NCIM 352 var. thermoidea, showed a biotechnological potential, especially in the production of cellulose pulp from agricultural residues. Further research on the action mechanisms of these enzyme systems is required to obtain an efficient degradation of fruit stalk waste into useful and low cost products (Krishna, 1999).

\section{References}

1. Archana A. and T. Satyanarayan. Xylanase production by thermophilic Bacillus. $A 99$ in solid-state fermentation. J. Enzyme and Microbial Technology. 1997, 21, 12-17.

2. Bradford, M.M. A rapid and sensitive method for the quantitation of microorganism quantities of protein utilizing the principle of protein dyes binding. Analytical Biochemistry. $1976,72,284-254$. 
3. Chen.chinshuh, Jam-lin chen and Tse-yang lin. Purification and characterization of a xylanase from Trichoderma longibractium for xylooligosaccharide production, J. Enzyme and Microbial Technology. 197, 21, 91.96.

4. Gardner, J.A.F., Hills, W.E. The influence of extractives on the pulping of wood in Wood Extroctives; Hillis, W.E.; Academic Press: New York, 1962, 367.402.

5. Krishna, C. Production of bacterial cellulase by solid-state bioprocessing of banana wastes. Bioresources Technology, 1999, 69(3), 231-299.

6. Kayak. L., Ratanakhanokchai, K., Uttapap, D., Tanticharoen, M. Induction of Xylanase in Bacillus circulans B6. Bioresour technol. 1994, 48, 163.167.

7. Miller, G.L. Use of dinitrosalicylic reagent for determination of reducing sugar. Anal. Chem. $1959,31,238-244$

8. Saraswat V, Bisaria V.S. Biosynthesis of xylanolytic and xylan-degrading enzymes in Melanocarpus albomyces IIS. J. Fermentation Bioengineering. 1997, 83, 352-357.

9. Ximene, F.A. Sousa, M.V; Puls, J. Silva, F.G., Kr; Filho, E.X.F. Purification and characterization of a low molecular weight xylanase produced by Acrophialophora nainiana 1999. Cur. Microbiol. 1999, 38, 18-21. 